\title{
Soil Surface Evaporation Control by Plant-based Mulching during the Energy Limiting and Falling Rate Evaporation Stages
}

\author{
T.N. Wickramaarachchi, R.C.W. Ranaweera and R.A.J.P. Kumara
}

\begin{abstract}
Huge quantities of plant by-products and plant wastes generated are stressing to assess their re-usability, probably as mulching, in conserving soil moisture. Magnitude and timing of evaporation reduction by mulching is vital in scheduling irrigation, particularly in dry areas. This study experimentally investigated the effects of six different plant based mulch treatments [coconut coir dust, coconut husk chips, Gliricidia leaves (Gliricidia Sepium), paddy straw, rice husk and saw dust] on controlling soil surface evaporation in sandy loam soil during the two stages of evaporation (energy limiting and falling rate) and degree of dependence of the soil surface evaporation on weather parameters. During the energy limiting evaporation stage, in comparison to the bare soil, all the mulch treatments exhibited the greatest differences in the soil surface evaporation rates (ANOVA, $p<0.05$ ) suggesting their suitability for high-frequency irrigation systems; Gliricidia leaves mulch performed best followed by rice husk mulch and saw dust mulch. Coconut coir dust, exhibiting statistically similar evaporation rates with the bare soil (Tukey's, $p>0.05$ ) during the falling rate evaporation stage, proved as the least effective mulch in providing prolonged evaporation restriction. Evaporation in saw dust mulched soil was highly dependent on temperature $(p<0.01)$ and relative humidity $(p<0.01)$ during the energy limiting stage.
\end{abstract}

Keywords: Energy limiting stage, Falling rate stage, Mulch, Plant by-products, Plant waste, Soil surface evaporation

\section{Introduction}

Several studies indicate that use of mulch can bring numerous advantages. Mulching is commonly used to conserve soil moisture in dry areas, mainly due to its ability to reduce soil evaporation by breaking capillarity [6], [8], [11], [12], [29]. The practice of mulching in agricultural farming must be presided over several decisive factors such as efficiency in retention of soil moisture, benefits to crop and soil, environmental sustainability, availability of material and overall cost. As a sustainable agricultural practice, organic mulching brings numerous positive effects on crop production other than conserving the soil moisture. Organic mulching has been shown to enhance root growth, soil fertility, yield and weed control [3], [5], [10], [14], [23], [26]. Moreover, it improves soil physical conditions, increases soil water retention capacity and facilitates water uptake by plants [4], [30]. Also, it helps to control soil erosion [18], [19], [22].

Use of organic mulching in the agricultural systems for improving crop performance has been the focus of many studies; however, only a few studies have been carried out to quantify the evaporation from soil surface due to the influence of different organic mulch types [27], [30]. Besides, large amounts of plant byproducts and plant wastes are generated annually around the world from a variety of sources. Efficient use of these organic wastes greatly reduces environmental pollution and brings positive impact to the economy [21]. In that context, there is a strong need to search for the functional efficiency of these organic wastes in using as mulch to conserve soil moisture, particularly in dry areas with irrigated farming.

Though the effect of mulch cover in reducing the soil surface evaporation is renowned, there is, however, a gap in knowledge that exists

Eng. (Dr.) (Mrs.) T.N. Wickramaarachchi, C. Eng., MIE(SL), B.Sc. Eng. (Hons) (Moratuwa), M.Phil.

(Moratuwa), PhD (Yamanashi), Senior Lecturer, Department of Civil and Environmental Engineering

University of Ruhuna, Sri Lanka.

Email:thushara@cee.ruh.ac.lk

ORCID ID: https://orcid.org/0000-0002-0274-2169

Eng. R.C.W. Ranaweera, AMIE (SL), B.Sc. Eng.

(Ruhuna).

Mr. R.A.J.P. Kumara, Undergraduate, Department of Civil and Environmental Engineering, Faculty of Engineering, University of Ruhuna, Sri Lanka. 
requiring to study: the effectiveness of fairly abundant plant based mulch materials in reducing the soil surface evaporation from the field capacity; the magnitude of their evaporation reduction during different stages of the evaporation process; and the influence of on-site weather parameters on the soil surface evaporation process, which have not been previously investigated. This study aims to contribute towards filling this gap.

Therefore, this study was carried out aiming to investigate the effect of six distinct organic mulch treatments (plant by-products and plant wastes commonly available in tropical region, not all of which previously studied) on the soil surface evaporation control during the two evaporation stages and to reveal the degree of dependence of mulched soil evaporation on onsite weather parameters. This study contributes to ascertain the effectiveness of widely used, abundant and easily available plant byproducts and plant wastes based mulch in controlling the soil surface evaporation and thereby to promote their use amongst cultivators.

\section{Materials and Methods}

\subsection{Experimental Site and Materials}

This experimental study was carried out in Hapugala area in Galle, located in southern

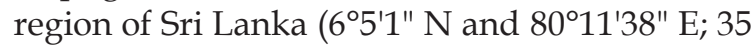
$\mathrm{m}$ altitude). Soil material available from Hapugala area was used in the experiment (consisted of $19 \%$ clay, $27 \%$ silt and $54 \%$ sand particles). The soil material was categorized as sandy loam as per the United States Department of Agriculture (USDA) soil triangle. Following air-drying, the soil was filtered through a $2 \mathrm{~mm}$ sieve. The experiment was conducted with six different types of plant by-products and plant wastes based mulch treatments: coconut coir dust, coconut husk chips, Gliricidia leaves, paddy straw, rice husk and saw dust.

Coconut coir dust: Coir dust is a major byproduct in the coconut fibre industry. During extraction of long fibre from coconut husk, the coir dust was obtained and it was a dusty material (particle size $<2 \mathrm{~mm}$ ). Coconut coir dust is widely used as mulch.

Coconut husk chips: Husk chips are produced from husk from the outer layer of coconut nut and consist of long fibers. Coconut husk was cut into $2 \mathrm{~cm} \times 1 \mathrm{~cm}$ size husk chips.
Gliricidia leaves: Leaves from Gliricidia trees (Gliricidia Sepium) readily available in the area were dried and used as mulch. Gliricidia belongs to legume family and the nitrogen-rich Gliricidia leaves were about $5.0 \pm 1.0 \mathrm{~cm}$ long and $2.0 \pm 1.0 \mathrm{~cm}$ wide.

Paddy straw: Paddy straw is a by-product produced when harvesting paddy. The average length of a strand of paddy straw used was 9.0 $\pm 2.0 \mathrm{~cm}$ with a diameter of approximately 0.5 $\mathrm{cm}$. Paddy straw is widely used as mulch.

Rice husk: During milling process, husks are removed from raw rice grain. Size of the rice husks used was $6 \mathrm{~mm}$ (long), on average.

Saw dust: Saw dust is obtained during sawing and milling operation of wood. It primarily consists of chips with lesser amount of dust. The average size of the saw dust chips used varied between $2.0 \times 2.0 \mathrm{~cm}$ for the largest and $0.5 \times 0.5 \mathrm{~cm}$ for the smallest.

A no mulch treatment (bare soil) was used as control. All mulch materials were air-dried for three weeks under similar environmental conditions.

According to Allen et al. [2], key climatic parameters influencing the soil surface evaporation have been identified as air temperature, relative humidity and wind speed. Throughout the period of the experiment, these parameters were measured on-site, together with pan evaporation measurements to determine atmospheric evaporation. Daily atmospheric evaporation was computed as the difference in water level in the pan on successive days, corrected for any precipitation [28]. Daily mean values of air temperature, relative humidity and wind speed ranged between $27-31^{\circ} \mathrm{C}, 67-85 \%$ and $1-3 \mathrm{~m} / \mathrm{s}$, respectively.

\subsection{Experimental Design}

$12 \mathrm{~cm}$ deep evaporation containers (having a 21 $\mathrm{cm}$ diameter at the soil surface) were used to pack the soil material along with $1.3 \mathrm{~g} / \mathrm{cm}^{3}$ bulk density value. Small holes at the bottom of the evaporation containers were screened in order to prevent the soil particles leaking through them. Water was applied to each evaporation container filled with soil by sprinkler irrigation to bring soil moisture into saturated level and kept for four days until the holes at the bottom of the evaporation containers were draining out gravitational water. During the four days, soil surface evaporation was prevented by placing a 
polythene cover on top of the containers and then weighed using a digital balance with accuracy of $0.01 \mathrm{~g}$. Thus, the experiment was conducted starting from the field capacity moisture content.

Onto the soil surface inside the container, mulch material was spread homogenously to 5 $\mathrm{cm}$ thickness. Bare soil surface without mulch treatment was considered as the control. Three replicates from each mulch treatment were used with a completely randomized experimental design. Soil surface evaporation was estimated from the changes in weights of the evaporation containers, which was measured at the same time everyday (8:00 am). The atmospheric evaporation was estimated everyday, based on the change in the evaporation pan's weight. Starting from $12^{\text {th }}$ October 2018, the experiment was conducted for 35 consecutive days under natural conditions. When it rained, polythene cover was placed on top of the evaporation containers.

\subsection{Calculation Procedure}

According to Allen et al. [2], subsequent to the application of water, the content of water in the surface soil layer is supposed to be at field capacity $\left(\varphi_{F C}\right)$ and, by drying the soil, the content of water in the soil could be brought midway between oven-dried and wilting point $\left(\varphi_{W P}\right)$. Thus, for duration of a complete drying cycle, total water depletion due to evaporation could be estimated by:

$W_{T E}=1000 x\left(\varphi_{F C}-0.5 \varphi_{W P}\right) Z_{d}$

where, $W_{T E}$ is the total evaporable water $(\mathrm{mm})$; $\varphi_{F C}$ is the field capacity soil water content $\left(\mathrm{m}^{3}\right.$ $\left.\mathrm{m}^{-3}\right) ; \varphi_{W P}$ is the wilting point soil water content $\left(\mathrm{m}^{3} \mathrm{~m}^{-3}\right)$; and $Z_{d}$ is the surface soil layer depth (m) [a value of $0.10-0.15 \mathrm{~m}$ is recommended for $\left.Z_{d}\right]$.

During the complete drying cycle, soil surface evaporation is supposed to occur covering two evaporation stages. During the first stage (energy limiting evaporation stage), the soil surface stays wet along with the maximum rate of evaporation occurring from the exposed soil surface which limits merely upon the availability of energy. This evaporation stage continues until the surface soil layer's hydraulic properties become restrictive, resulting limited upward water movement through the soil profile which could not satisfy the potential demand. Energy limiting evaporation stage comes to an end when the cumulative depth of evaporation is equal to readily evaporable water $\left(W_{R E}\right)$. The second stage (falling rate evaporation stage) starts when the cumulative depth of evaporation exceeds $W_{R E}$. Evaporation continues to fall during this stage in proportion to the quantity of remaining water in the surface soil layer with a noticeably dry soil surface. $W_{R E}$ is estimated based on soil texture. For fine textured soils, $W_{R E}$ is highest and it usually varies from 2 to $12 \mathrm{~mm}$.

The atmospheric evaporation is given as $E_{a}$ ( $\mathrm{mm} /$ day) and the soil surface evaporation is given as $E_{s}(\mathrm{~mm} /$ day).

$E_{a i}(i=1,2, \ldots \ldots ., 35)$ is the $i^{\text {th }}$ day's atmospheric evaporation which is given by:

$E_{a i}=E_{\text {mpi }} \times 10^{4} / A_{\text {pan }}$

where, $E_{m p i}$ is the evaporation pan's weight change on the $i^{\text {th }}$ day $\left(\mathrm{kg} /\right.$ day); $A_{\text {pan }}$ is the surface area of the evaporation pan $\left(\mathrm{cm}^{2}\right)$.

$E_{s i}(i=1,2, \ldots \ldots . .35)$ is the $i^{\text {th }}$ day's soil surface evaporation which is given by:

$E_{s i}=E_{\text {mci }} \times 10^{4} / A_{\text {soil }}$

where, $E_{m c i}$ is the evaporation container's weight change on the $i^{\text {th }}$ day $\left(\mathrm{kg} /\right.$ day); $A_{\text {soil }}$ is the surface area of the soil $\left(\mathrm{cm}^{2}\right)$.

According to Yuan et al. [29], calculation of dry soil mass $\left(W_{s}\right)$ is done according to equation (4).

$W_{s}=W_{d s} /\left(\varphi_{d s}+1\right)$

where, air-dried soil's water content is $\varphi_{d s}$ $\left(\mathrm{m}^{3} \mathrm{~m}^{-3}\right)$; air-dried soil's mass is $W_{d s}(\mathrm{~kg})$.

Estimation of the $i^{\text {th }}$ day's soil water mass $\left(W_{i}\right)$ and the $i^{\text {th }}$ day's soil water content $\left(\varphi_{i}\right)$ are done according to equation (5) and equation (6), respectively.

$W_{i}=W_{i-1}-E_{m c(i-1)}(i=2,3, \ldots, 35)$

$\varphi_{i}=W_{i} / W_{s}(i=1,2, \ldots, 35)$

The daily averaged $\varphi_{i}$ was estimated throughout the duration of the drying process (35 days).

\subsection{Data Analysis}

Analysis of variance (ANOVA) method was used to analyze the differences in the soil surface evaporation between different mulch treatments and the bare soil. Tukey's multiple comparison test at $p=0.05$ was applied to evaluate the significance of differences in means. Spearman rank correlation coefficient was used to determine the strength of correlation between the soil surface evaporation and the climatic variables (air temperature, relative humidity and wind). IBM SPSS statistics 23 statistical software package was used in the data analysis. 


\section{Results and Discussion}

\subsection{Evaporation Mechanism in the} Mulched Soil

Schematic representation of the soil surface evaporation in mulched soil is shown in Figure 1. Evaporation from a soil surface is an energy activated procedure in which soil moisture moves upward due to capillary force and from the top soil layer, the moisture diffuses into the air in the form of vapour. Mulching prevents direct reaching of solar radiation to the soil surface and thereby reducing evaporation due to retardation of energy reaching the mulched surface. Thus, the soil surface evaporation is considerably lessened owing to reduced heat energy absorption. Besides shielding direct reach of solar radiation, mulching establishes resistance to heat flowing to further deep soil layers. In addition, mulching breaks capillary continuity to reduce water movement inside the macro pores among mulch fragments which weaken the vapour diffusion to the atmosphere. Typically, very high moisture or vapour held among the pores owing to lessened vapour diffusion result in reduced soil surface evaporation [16], [25], [29].

\subsection{Soil Surface Evaporation in Mulched} Soil and Bare Soil

\subsubsection{Soil surface evaporation} $\left(E_{s}\right) /$ atmospheric evaporation $\left(E_{a}\right)$ variation with soil water content

With the soil moisture content at the field capacity, the evaporation process was started.
$E_{s}$ value for each mulch treatment was calculated based on the average value obtained from the three replicates. According to Figure 2 , the $E_{s} / E_{a}$ values of the mulch treatments and the bare soil showed close relation with the soil water content as described below.

Irrespective of the mulch type, all mulch treatments reduced the soil surface evaporation significantly in comparison to the bare soil. Content of the soil water, mulching and weather condition found to be the most influential factors for the soil surface evaporation [29]. During this experiment, the mulching and soil water content were influencing the soil surface evaporation since the weather conditions remained similar for both bare soil and mulched soil evaporation.

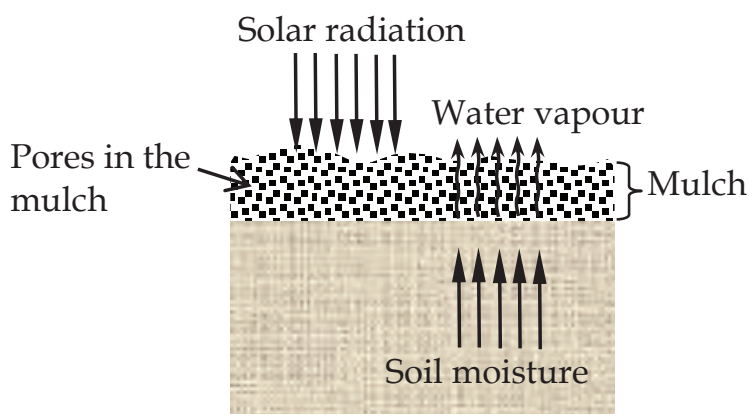

Figure 1 - Schematic Representation of the Soil Surface Evaporation in Mulched Soil

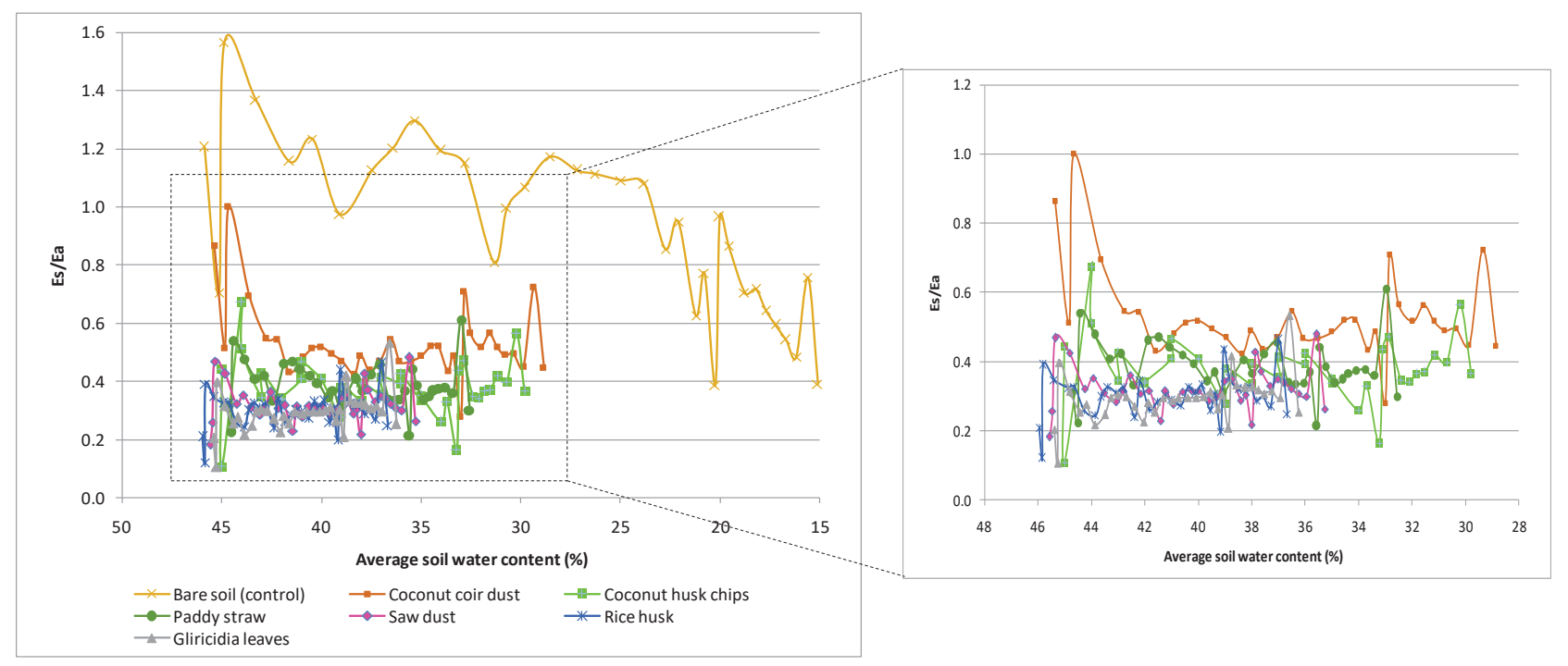

Figure $2-E_{s} / E_{a}$ Variation with Soil Water Content 
Table 1 - Soil Surface Evaporation Rates during Different Stages of the Drying Cycle

\begin{tabular}{|c|c|c|c|c|}
\hline \multirow{4}{*}{$\begin{array}{l}\text { Number of days } \\
\begin{array}{l}\text { Stage of the drying } \\
\text { cycle }\end{array}\end{array}$} & \multirow{2}{*}{\multicolumn{3}{|c|}{ Average soil surface evaporation rate (mm/day) }} & \multirow{4}{*}{$\begin{array}{l}\text { Significance level } \\
\text { of the difference } \\
\text { between the } \\
\text { energy limiting } \\
\text { stage and the } \\
\text { falling rate stage }\end{array}$} \\
\hline & & & & \\
\hline & $1-7$ & $8-21$ & $22-35$ & \\
\hline & $\begin{array}{c}\text { Energy } \\
\text { limiting stage }\end{array}$ & $\begin{array}{l}\text { Energy limiting } \\
\text { stage or falling } \\
\text { rate stage }\end{array}$ & $\begin{array}{l}\text { Falling rate } \\
\text { stage }\end{array}$ & \\
\hline Bare soil (control) & $\begin{array}{c}1.17 \mathrm{a} \\
(100 \%)\end{array}$ & $\begin{array}{l}1.09 \mathrm{a} \\
(100 \%)\end{array}$ & $\begin{array}{c}0.53 a \\
(100 \%)\end{array}$ & 0.01 \\
\hline Coconut coir dust & $\begin{array}{c}0.62 \mathrm{~b} \\
(52.99 \%)\end{array}$ & $\begin{array}{c}0.48 b \\
(44.04 \%)\end{array}$ & $\begin{array}{c}0.41 \mathrm{a} \\
(77.36 \%)\end{array}$ & 0.05 \\
\hline Coconut husk chips & $\begin{array}{c}0.42 b \\
(35.90 \%)\end{array}$ & $\begin{array}{c}0.39 \mathrm{~b} \\
(35.78 \%)\end{array}$ & $\begin{array}{c}0.30 \mathrm{~b} \\
(56.60 \%)\end{array}$ & Not significant \\
\hline $\begin{array}{l}\text { Gliricidia leaves } \\
\text { mulch }\end{array}$ & $\begin{array}{c}0.27 \mathrm{~b} \\
(23.08 \%)\end{array}$ & $\begin{array}{c}0.27 \mathrm{~b} \\
(24.77 \%)\end{array}$ & $\begin{array}{c}0.25 \mathrm{~b} \\
(47.17 \%)\end{array}$ & Not significant \\
\hline Paddy straw & $\begin{array}{c}0.40 \mathrm{~b} \\
(34.19 \%)\end{array}$ & $\begin{array}{c}0.38 \mathrm{~b} \\
(34.86 \%)\end{array}$ & $\begin{array}{c}0.29 \mathrm{~b} \\
(54.72 \%)\end{array}$ & Not significant \\
\hline Rice husk & $\begin{array}{c}0.30 \mathrm{~b} \\
(25.64 \%)\end{array}$ & $\begin{array}{c}0.29 \mathrm{~b} \\
(26.61 \%)\end{array}$ & $\begin{array}{c}0.26 \mathrm{~b} \\
(49.06 \%)\end{array}$ & Not significant \\
\hline Saw dust & $\begin{array}{c}0.34 b \\
(29.05 \%)\end{array}$ & $\begin{array}{c}0.30 \mathrm{~b} \\
(27.52 \%)\end{array}$ & $\begin{array}{c}0.27 b \\
(50.94 \%)\end{array}$ & Not significant \\
\hline
\end{tabular}

Notes:

The values followed by the same letter within each column denote that they are not significantly different at the 0.05 probability level.

Evaporation process started with the soil water content around $45 \%$. Evaporation process of the bare soil started with very high $E_{s} / E_{a}$ values (greater than 1.0). Bare soil showed fast soil surface evaporation with rapidly decreasing soil water content during the 35 days consecutive evaporation procedure. Initially, the soil water content was not influencing the soil surface evaporation. However, due to this initial intensive evaporation, soil water availability was limited for the subsequent process of evaporation. During the last few days, the $E_{s} / E_{a}$ values of the bare soil reached a more or less stable value (about 0.50 ) with the soil water content of $15 \%$.

For the coconut coir dust mulch, the $E_{s} / E_{a}$ value was about 0.90 at the start of the evaporation process. During the initial few days, the evaporation and the soil water decrease was fast. But with the continued evaporation process, the $E_{s} / E_{a}$ values and the soil water content gradually and slowly decreased to values of about 0.45 and $28 \%$, respectively.

For the coconut coir dust mulch, the $E_{s} / E_{a}$ values were generally greater than the $E_{s} / E_{a}$ values of the other mulch treatments, but considerably lower than the $E_{s} / E_{a}$ values of the bare soil, throughout the evaporation process. At the field capacity, the $E_{s} / E_{a}$ values under the mulch treatments of coconut husk chips and paddy straw were about 0.60 and 0.50 , respectively. During the evaporation process, their $E_{s} / E_{a}$ values and the soil water contents gradually and slowly decreased to values of about 0.35 and $30 \%$, respectively. For the mulch treatments of Gliricidia leaves, rice husk and saw dust, the $E_{s} / E_{a}$ values had no significant decrease and remained more or less stably around 0.30 with slow reduction in the soil water contents towards $36 \%$, during the evaporation process.

Thus, a controlled soil surface evaporation was exhibited for the soil with mulch treatments. For the soil with mulch treatments, the soil water loss was slowed from the start to the end of the evaporation process compared to even weak soil surface evaporation occurring in the bare soil due to the lowered availability of soil water, particularly during the latter period of the evaporation process. Kakaire et al. [13] and Yuan et al. [29], who showed that the soil surface evaporation flux was affected by the 
moisture conserving capacity of the mulches, further confirmed the above finding.

\subsubsection{Soil Water Reduction from the Field Capacity}

Starting from the field capacity, as the evaporation proceeded for 35 days, the soil water content of the bare soil decreased by $68 \%$, while those under mulch treatment of coconut coir dust, coconut husk chips, paddy straw, saw dust, rice husk and Gliricidia leaves exhibited decrease of $38 \%, 33 \%, 28 \%, 23 \%, 21 \%$ and $20 \%$, respectively. On the other hand, in the soils protected by the mulches, high retention of soil water contents was apparent. The retention of soil water was significantly high in Gliricidia leaves mulched soil (80\%) followed by rice husk mulched soil $(79 \%)$ and saw dust mulched soils (77\%), in comparison to the bare soil. The soil water reduction from the field capacity in natural environment (ranging between $45 \%-15 \%$ ) as found in this study could be described in order by: in bare soil $>$ in coconut coir dust mulched soil $>$ in coconut husk chips mulched soil $>$ in paddy straw mulched soil $>$ in saw dust mulched soil $>$ in rice husk mulched soil $>$ in Gliricidia leaves mulched soil.

\subsection{Soil Surface Evaporation during Different Stages of the Drying Cycle}

\subsubsection{Comparison of Soil Surface Evaporation Rates}

Soil surface evaporation rates during the different evaporation stages (energy limiting and falling rate) were determined. Moisture content of the soil was at field capacity at the beginning of the energy limiting stage which considered a fully saturated condition. For the sandy loam soil, amount of $W_{R E}$ was estimated as $8 \mathrm{~mm}$ during the energy limiting stage [2].

For each soil mulch treatment and bare soil, average daily soil surface evaporation rates were determined during the different stages of the drying cycle (Table 1). The average daily soil surface evaporation rates that occurred under the mulch treatments with respective to the bare soil are stated as a percentage value inside the parenthesis.

During the first seven days of the energy limiting stage, the soil surface evaporation rates occurred under different mulch treatments compared to the bare soil showed statistically significant difference as determined by one-way ANOVA $(F(6,42)=$
10.02, $p<0.05)$. Mulch treatments have been significantly contributing to reduce the soil surface evaporation from the field capacity by: $77 \%$ in Gliricidia leaves, $74 \%$ in rice husk, $71 \%$ in saw dust, $66 \%$ in paddy straw, $64 \%$ in coconut husk chips, and $47 \%$ in coconut coir dust, compared to the bare soil. Use of the mulch treatments showed a decrease in the soil surface evaporation rates by about $50 \%$ to $75 \%$ in comparison to the bare soil $(p<0.05)$. Moreover, the soil surface evaporation rates were statistically similar (Tukey's, $p>0.05$ ) among all the mulch treatments during the first seven days of the energy limiting stage. The lowest $(0.27 \mathrm{~mm} /$ day $)$ and the highest $(0.62 \mathrm{~mm} /$ day $)$ values were shown for the Gliricidia leaves treatment and the coconut coir dust treatment, respectively (Table 1).

During the 8-21 days (either energy limiting stage or falling rate stage, contingent upon the mulch treatment) also, Gliricidia leaves treatment demonstrated the highest (75\%) evaporation reduction and coconut coir dust treatment demonstrated the lowest (56\%) evaporation reduction, compared to the bare soil. However, during that period also, there existed statistically different (ANOVA, $p<0.05$ ) soil surface evaporation rates between the bare soil and all the mulch treatments. Moreover, the soil surface evaporation rates among all the mulch treatments were statistically similar (Tukey's, $p>0.05$ ) (Table 1).

Other than the mulch treatments protecting the soil surface from water vapor loss, during the falling rate stage, the evaporating surface in the bare soil is shielded by a dry soil layer which resists inward solar radiation and thereby providing a barrier to downward movement of heat resulting in reduced water vapor loss from the soil surface [7]. Thus, the bare soil was having a dried top soil shield other than the lowered soil water content, during the falling rate stage. Though it is expected that more water retained in the mulched soil would result in greater evaporation compared to the bare soil, evaporation was always lower from the mulched soil in the falling rate stage due to the resistance to water loss provided by the mulching. Except for coconut coir dust, for all the other mulch treatments, mulched soil and bare soil evaporation rates showed statistically significant difference during the falling rate stage $(F(6,91)=18.93, p<0.05)$. Coconut coir dust mulch and the bare soil showed statistically similar (Tukey's, $p>0.05$ ) soil 
surface evaporation rates. Soil surface evaporation rates in the coconut coir dust treatment decreased by about 23\% $\quad(p>0.05)$ while in the other mulch treatments, the decreases were about $50 \%(p<0.05)$ compared to the bare soil during the falling rate stage (Table 1). Thus, it is clear that the evaporation reductions have been reduced from the first stage of the drying cycle (energy limiting evaporation stage) to the second stage of the drying cycle (falling rate evaporation stage), highlighting that mulching would be most effective in the energy limiting stage.

\subsubsection{Effectiveness of Mulch Treatments in Controlling the Soil Surface Evaporation}

During the energy limiting stage, the soil surface evaporation that occurred between the mulched and the bare soil showed the greatest differences, highlighting that the mulch treatments were most effective during the energy limiting stage (Table 1). Studies carried out by Ji and Unger [11] and Zribi et al. [30] have also revealed that mulches were beneficial for controlling evaporation and conserving water by decreasing the initial evaporation rates. Moreover, during the energy limiting stage, it was likely that the mulched soils were requiring between two to four times longer to lose the same quantity of water in comparison to the bare soil. According to Acharya et al. [1], this slowing down of evaporation in the initial stage enhanced the procedure of inner movement of water further deep, which will retain longer and less susceptible to evaporation. As well, Todd et al. [24] has revealed that compared to the bare soil, mulched soil was reducing the evaporation and the reduced amount was higher at high soil water contents and lower at low soil water contents, which agreed with the present study as presented in Table 1.

According to Table 1, between the energy limiting stage and the falling rate stage, statistically significant difference in the soil surface evaporation rates was shown only for the bare soil $(F(2,32)=6.94, p<0.01)$ and the coconut coir dust mulched soil $(F(2,32)=4.29$, $p<0.05)$. Coconut coir dust proved to be the least effective in acting as mulch with regard to the soil moisture conservation in the long run. For all the other mulch treatments, difference in the soil surface evaporation rates between the two evaporation stages was not statistically significant $(p>0.05)$. This further confirms prolonged soil evaporation restriction provided by the mulched soils (except for coconut coir dust) throughout the evaporation process, other than to the prominent soil evaporation restriction evident during the energy limiting stage.

Among all the treatments, contrasting results were obtained for the coconut coir dust treatment which seems less beneficial in controlling the soil surface evaporation. Coconut coir dust mulch, having the finest particles, was very much less efficient in the soil surface evaporation control compared to all other mulches. This apparent discrepancy might be due to the finer pores of the coconut coir dust transferring the water present at the soil surface to the atmosphere as water vapour through capillarity which enhanced evaporation. Comparatively larger fragments of the other mulch materials forming larger and patchy pores reduced the water flowing rate in the upward direction as a consequence of capillary break resulting reduced evaporation. Evaporation suppression due to coarse-textured mulch overlying fine-textured layer was well established by previous studies since the coarse-textured mulch layer was acting as a barrier for water flowing in the upward direction and evaporation [16], [20], [30].

Present study revealed that the Gliricidia leaves mulch is clearly the most effective in controlling the soil surface evaporation compared to the other mulches. Besides its effectiveness as mulch, decaying Gliricidia leaves also become a source of plant nutrients, by adding nitrogen to the soil [9]. Overall, the results obtained in the study indicated that all the mulch treatments would be most effective in controlling the soil surface evaporation during the energy limiting stage in which the soil surface remains wet. This agrees with Myburgh [17], Uzoma and Onwuka [27] and Zribi et al. [30] who found that soil mulching is mostly advantageous in irrigation schemes with frequent water applications where the soil surface stays wet more often, while it is less advantageous in low frequency irrigation schemes in which the soil surface stays dry most of the time.

3.4

\section{Soil Surface Evaporation Correlations with Temperature, Relative Humidity and Wind}

Statistically significant positive correlation that existed between the soil surface evaporation and temperature during the energy limiting 
stage was determined by Spearman's rank correlation analysis: for the saw dust mulch, the correlation was significant at the 0.01 level; for the other mulch treatments and the bare soil, the correlations were significant at the 0.05 level. Statistically significant negative correlation existed between the soil surface evaporation and relative humidity during the energy limiting stage showed that: for bare soil, paddy straw, rice husk and saw dust, the correlations were significant at the 0.01 level; for all other mulch treatments, the correlations were significant at the 0.05 level. However, during the falling rate stage, above correlations were not statistically significant. This finding is also supported by Lehmann et al. [15] who revealed that evaporation occurring during the energy limiting stage was limited mostly by the atmospheric conditions. The soil surface evaporation and wind have not shown statistically significant correlation in both stages.

The highest correlation coefficients $(\approx 0.9)$ and the strongest correlations $(p<0.01)$ between the soil surface evaporation and the weather parameters (relative humidity and temperature) were exhibited for the saw dust mulch. Thus, the soil surface evaporation in the saw dust mulch proved to be much dependent on weather parameters (relative humidity and temperature) compared to the soil surface evaporation in the bare soil and other mulch treatments.

\section{Conclusion}

Particularly in dry areas, reduction of the soil surface evaporation through farming practices is vital. This study determined the effectiveness of fairly abundant plant byproducts and plant wastes in the tropical region as mulch materials in controlling the soil surface evaporation. Evaporation from the soil surface depended on the type of mulch material and the evaporation stage (either energy limiting evaporation stage or falling rate evaporation stage). Out of the six mulch treatments tested, Gliricidia leaves mulch performed best in controlling the soil surface evaporation followed by rice husk mulch and saw dust mulch, compared to the bare soil. Coconut coir dust treatment found to be the least effective in controlling the soil surface evaporation, particularly during the falling rate stage. Reductions in the soil surface evaporation have been reduced from the energy limiting stage to the falling rate stage.
Nevertheless, all mulch treatments were successful in controlling the soil surface evaporation; however, they were primarily effective during the energy limiting stage. This made evident that plant by-products based and plant wastes based mulch materials would be most effective in controlling the soil surface evaporation in irrigation schemes with frequent water applications where the soil surface stays wet more often. Saw dust mulch showed a statistically significant tendency that the evaporation losses were highly influenced by the relative humidity and the temperature.

Findings of the study reinforce interest to utilize plant by-products and plant wastes as beneficial mulch for controlling the water loss by evaporation, particularly in high-frequency irrigation systems whilst adding value to the huge quantity of plant by-products and plant wastes generated. Moreover, incorporation of these mulch materials into the soil will bring numerous benefits to crop growth, for example, Gliricidia leaves besides being the most effective mulch in controlling the soil surface evaporation, release nutrients (nitrogen) to the soil on decomposition. Most importantly, further studies are required to comprehend the effects of composite mulching and their thickness on controlling the evaporation from soil surfaces having different textures than the sandy loam soil used in this study.

\section{Acknowledgement}

Authors wish to acknowledge the financial support provided by the Research Fund of University of Ruhuna, Sri Lanka in conducting this research.

\section{References}

1. Acharya, C. L., Hati, K. M., \& Bandyopadhyay, K. K., Mulches. In: D. Hillel (Ed.), Encyclopedia of Soil in the Environment, Elsevier Ltd, 2005, pp. 521-532.

2. Allen, R. G., Pereira, L. S., Raes, D., \& Smith, M., Crop Evapotranspiration, Guidelines for Computing Crop Water Requirements, FAO Irrigation and Drainage Paper 56, FAO, Rome, Italy, 1998.

3. Bajgai, Y., Kristiansen, P., Hulugalle, N., \& McHenry, M., "Effect of Residue Management and Conventional and Organic Soil Management Systems on Crop Yields and Weed Biomass", Acta. Hortic., Vol. 1018, 2014, pp. 227-234.

4. Cook, H. F., Valdes, G. S. B., \& Lee, H. C., “Mulch Effects on Rainfall Interception, Soil Physical Characteristics and Temperature under Zea 
mays L. ", Soil Tillage Res., Vol. 91, 2006, pp. 227235.

5. Devasinghe, D. A. U. D., Premarathne, K. P., \& Sangakkara, U. R., "Weed Management by Rice Straw Mulching in Direct Seeded Lowland Rice (Oryza sativa L.) ", Trop. Agric. Res., Vol. 22, No. 3, 2011, pp. 263-272.

6. Díaz, F., Jiménez, C. C., \& Tejedor, M., "Influence of the Thickness and Grain Size of Tephra Mulch on Soil Water Evaporation", Agric. Water Manag., Vol. 74, 2005, pp. 47-55.

7. Enrique, A. T., \& Alfonso, C., "Bare Soil Evaporation under High Evaporation Demand: A Proposed Modification to the FAO-56 Model", Hydrol. Sci J., Vol. 55, No. 3, 2010, pp. 303-315.

8. Fuchs, M., \& Hadas, A., "Mulch Resistance to Water Vapor Transport", Agric. Water Manag., Vol. 98, No. 6, 2011, pp. 990-998.

9. Gutteridge, R. C., "Evaluation of the Leaf of a Range of Tree Legumes as a Source of Nitrogen for Crop Growth", Exp. Agr., Vol. 28, No.2, 1992, pp. 195-202.

10. Haynes, R. J., “Influence of Soil Management Practice on the Orchard Agro-Ecosystem", Agro Ecosyst., Vol. 6, No. 1, 1980, pp. 3-32.

11. Ji, S., \& Unger, P. W., "Soil Water Accumulation under Different Precipitation, Potential Evaporation, and Straw Mulch Conditions", Soil Sci. Soc. Am. J., Vol. 65, No. 2, 2001, pp. 442-448.

12. Jordán, A., Zavala, L. M., \& Gil, J., "Effects of Mulching on Soil Physical Properties and Runoff under Semi-Arid Conditions in Southern Spain", Catena, Vol. 81, No. 1, 2010, pp. 77-85.

13. Kakaire, J., Makokha, G. L., Mwanjalolo, M., Mensah, A. K., \& Menya, E., "Effects of Mulching on Soil Hydro-Physical Properties in Kibaale Subcatchment, South Central Uganda", Appl. Ecol. Env. Sci., Vol. 3, No. 5, 2015, pp. 127135.

14.Kumar, S., \& Dey P., “Effects of different Mulches and Irrigation Methods on Root Growth, Uptake, Water-Use Efficiency and Yield of Strawberry", Sci. Hortic., Vol. 127, No. 3, 2011, pp. 318-324.

15. Lehmann, P., Assouline, S., \& Or, D., "Characteristic Lengths Affecting Evaporative Drying of Porous Media", Phys. Rev. E., Vol. 77, 056309, 2008.

16. Li, X. P, Chang, S. X., \& Salifu, K. F., "Soil Texture and Layering Effects on Water and Salt Dynamics in the Presence of a Water Table: A Review", Environ. Rev., Vol. 22, No. 1, 2014, pp. $41-50$.
17. Myburgh, P. A., "Effect of Shallow Tillage and Straw Mulching on Soil Water Conservation and Grapevine Response", S. Afr. J. Plant Soil., Vol. 30, No. 4, 2013, pp. 219-225.

18. Omoro, L. M. A., \& Nair, P. K. R., "Effects of Mulching with Multipurpose-Tree Prunings on Soil and Water Runoff under Semiarid Conditions in Kenya", Agroforest. Syst., Vol. 22, No. 3, 1993, pp. 225-239.

19. Rees, H., Chow, T., Loro, P., Lavoie, J., Monteith, J., \& Blaauw, A., "Hay Mulching to Reduce Runoff and Soil Loss under Intensive Potato Production in Northwestern New Brunswick", Canada. Can. J. Soil Sci., Vol. 82, No. 2, 2002, pp. 249-258.

20. Shokri, N., Lehmann, P., \& Or, D., “Evaporation from Layered Porous Media", J. Geophys. Res., Vol. 115, B06204, 2010.

21. Singh, R., Yadav, D. B., Ravisankar, N., Yadav A., \& Singh H., "Crop Residue Management in Rice-Wheat Cropping System for Resource Conservation and Environmental Protection in North-Western India", Environ. Dev. Sustain., Vol. 22, 2020, pp. 3871-3896.

22. Smets, T., Poesen J., \& Knapen A., "Spatial Scale Effects on the Effectiveness of Organic Mulches in Reducing Soil Erosion by Water", Earth Sci. Rev., Vol. 89, No. 1-2, 2008, pp. 1-12.

23. Tian, G., \& Brussaard, L., "Mulching Effect of Plant Residues of Chemical Contrasting Compositions on Soil Organic Matter Content and Cation Exchange Capacity", Commun. Soil Sci. Plant Anal., Vol. 28, No. 17-18, 1997, pp. 1603-1611.

24. Todd, R. W., Klocke, N. L., Hergert, G. W., \& Parkhurst, A. M., "Evaporation from Soil Influenced by Crop Shading, Crop Residue, and Wetting Regime", Tans. ASAE., Vol. 34, No. 2, 1991, pp. 461-466.

25. Torres, E. A., \& Calera, A., "Bare Soil Evaporation under High Evaporation Demand: A Proposed Modification to the FAO-56 Model", Hydrol. Sci. J., Vol. 55, No. 3, 2010, pp. 303-315.

26. Tosic, I., Zarko, I., \& Maksimovic, I., "The Effect of Plant Mulching and Covering on the Lettuce Yield and Nitrate Content (Lactuca sativa) ", Afr. J. Agri. Res., Vol. 9, No. 23, 2014, pp. 1774-1777.

27. Uzoma, K. C., \& Onwuka, B. M., "Effects of Organic Mulch Materials on Soil Surface Evaporation", Not. Sci. Biol., Vol. 10, No. 3, 2018, pp. 387-391. 
28. WMO, The Guide to Hydrological Practices (WMO No.168), Volume I: Hydrology - From Measurement to Hydrological Information, $6^{\text {th }}$ ed., World Meteorological Organization, Geneva, 2008.

29. Yuan, C. P., Lei, T. W., Mao, L. L., Liu, H., \& Wu, Y., "Soil Surface Evaporation Processes under Mulches of Different Sized Gravel", Catena, Vol. 78, No. 2, 2009, pp. 117-121.

30. Zribi, W., Aragüés, R., Medina, E., \& Faci, J. M., "Efficiency of Inorganic and Organic Mulching Materials for Soil Evaporation Control", Soil Tillage Res., Vol. 148, 2015, pp. 40-45. 